Pengembangan Sistem Peningkatan Motivasi, Komitmen Dan Moralitas SDM...

\title{
PENGEMBANGAN SISTEM PENINGKATAN MOTIVASI, KOMITMEN DAN MORALITAS SDM DI LEMBAGA PENDIDIKAN ISLAM
}

\author{
Fauzan Adhim
}

Dosen IAI Al Falah As Sunniyyah Kencong Jember

\begin{abstract}
Its role determines the succession of the process of administering education. Ignoring human resources is the same as making a death hole for educational institutions. It is on the basis of the urgency of human Resources that the concept and model of human Resources management emerge in educational institutions. In general, the concept can be categorized into two models. [1] human Resources as a person who has motivation, commitment and morality. Thus, the management efforts carried out must be in order to improve the overall personality above; [2] human Resources as a unified system in educational institutions. The efforts made by the manager are to build a system and a model that becomes a reference and performance guide for all human Resources. human Resources motivation is related to psychological drives that are influenced by two factors, namely internal and external, or intrinsic and extrinsic. Internal factors can be influenced by basic human needs as Maslow's theory. human Resources commitment is related to identification of feelings, participation and loyalty to the organization. So if you want to know someone's commitment then you can see their loyalty to the organization.
\end{abstract}

Keyword: Motivation, Commitment and Morality, Human Resources

\section{PENDAHULUAN}

Salah satu komponen penting dalam manajemen lembaga pendidikan Islam adalah SDM. Dengan SDM yang profesional, lembaga pendidikan Islam akan mengalami perkembangan dan progresifitas yang bekelanjutan. Oleh sebab itu, SDM harus kelola dengan baik mulai dari perencanaan, penataan, hingga pada peningkatan kualitasnya. Melalui rekrutmen hingga evaluasi SDM harus benarbenar dilakukan secara serius dengan menduhulukan prinsip kebutuhan, efektifitas, efisien dan produktifitas. Hal ini dilakukan untuk mengantisipasi adanya over load dalam tubuh organisasi.

Tahapan penting yang harus diperhatikan dalam manajemen sumber daya manusia adalah induksi. Dengan induksi, pimpinan lembaga pendidikan akan mengetahui besarnya kecilnya motivasi anggota, tinggi rendahnya komitmen dan

FALASIFA, Vol. 9 Nomor 2 September 2018 | 21 


\section{Fauzan Adhim}

baik buruknya moralitas anggota. Mengingat, tiga bentuk dorongan psikis tersebut banyak memengaruhi terhadap profesionalitas kerja pengelola di lembaga pendidikan. Mereka yang memiliki motivasi, komitmen dan moralitas kerja yang baik, cenderung menampilkan perilaku kerja yang sesuai dengan kepentingan dan tujuan organisasi. Walaupun menyakut mental individu, namun penting bagi pemimpin untuk menumbuh kembangan dorongan-dorongan tersebut melalui pendekatan sistem, budaya kerja dan lainya.

Dalam Lembaga Pendidikan Islam, motivasi, komitmen dan moral SDM seyogyanya harus lebih mapan dibadingkan dengan institusi lainnya, karena secara faktual, lembaga pendidikan Islam masih cenderung stagnan. Oleh sebab itu dibutuhkan amunisi, motivasi, komitmen dan moralitas kerja yang lebih dibandingkan dengan lembaga lainnya. Sehingga image lembaga pendidikan Islam yang suka bermalas-malasan, tidak memiliki etos kerja, dapat berubah seiring dengan perkembangan waktu.

Adapun konsepsinya, penulis mencoba mengurai unsur-unsur penting, dimensi-dimensi inti melalui pendekatan teori-teori tentang motivasi, komitmen, dan moralitas SDM dari berbagai tokoh. Uraian ini diharapkan dapat memberikan formulasi teoritis dalam rangka pengembangan sistem peningkatan komitmen, motivasi dan moralitas kerja SDM lembaga pendidikan Islam.

\section{PEMBAHASAN}

\section{Motivasi SDM Lembaga Pendidikan Islam}

Dalam diskurusus manajemen SDM, Robbin mendefinisikan motivasi sebagai keinginan untuk melakukan sesuatu sebagai bentuk kesediaan untuk menampilkan usaha dan upaya demi kepentingan organisasi. Upaya-upaya tersebut digerakkan oleh kebutuhan individul. Sementara menurut Rivai, motivasi merupakan serangkaian sikap dan nilai-nilai yang memengaruhi individu untuk mencapai hal yang spesifik sesuai tujuan individu. Sikap dan nilai tersebut memberikan dorongan terhadap individu dalam melakukan aktifitas yang sesuai dengan kepentingan organisasi.2

Dua pengertian motivasi di atas memberikan pemahaman bahwa motivasi adalah dorongan psikis yang dapat menggerakan seseorang untuk melakukan suatu tindakan dan perilaku tertentu. Dorongan-dorongan tersebut bisa berkaitan dengan kebutuhan-kebutuhan individu namun juga terdapat kebutuhan yang diri

\footnotetext{
${ }^{1}$ Robbins P. Stephen, Perilaku Organisasi, Alih Bahasa: Tim Indeks, (Jakarta: PT. Indeks Kelompok Gramedia, 2003), hlm,. 55

${ }^{2}$ Rivai Veithzal, Manajemen Sumber Daya Manusia untuk Perusabaan, (Jakarta: PT. Raja Grafindo Persada, 2005), hlm. 455
}

22 | FALASIFA, Vol. 9 Nomor 2 September 2018 
yang berkaitan dengan kepentingan sosial. Catatan penting dari pengertian di atas, bahwa dorongan atau keinginan yang dipengaruhi oleh kebutuhan individual tersebut harus selaras, sesuai dengan kepentingan besar organisasi.

\section{Konsep Dasar Teori Motivasi}

Teori motivasi telah mengalami perkembangan dan penyempurnaan yang cukup panjang, sehingga dapat dikategorikan menjadi dua kelompok besar yaitu: ${ }^{3}$

\section{Content Theory}

Teori ini merupakan teori klasik yang didasarkan pada kebutuhan dan kepuasan individu. Adapun teori yang tergolong dalam kelompok ini adalah:

a) Teori Hirarki Kebutuhan [Abraham Maslow], meliputi: [1] Fisiologis, hal ini berkaitan dengan kebutuhan seseorang dari sisi jasmani, seperti, makan, minum, berpakaian, rumah, seksual dan lainnya. [2] Keamanan, berkaitan dengan kebutuhan individu akan keamanan dirinya secara fisik dan emosional. [3] Sosial, kebutuhan untuk dicintai oleh sesama, bekomunikasi dan berintraksi dengan orang lain.[4] Penghargaan dan pengakuan, yang mencakup pada apresiasi psikis yang dibutuhkan oleh individu.[5] Aktualisasi, yang berhubungan dengan kebutuhan seseorang dalam mengekspresikan diri secara fisik dan intelektual.

b) Teori Tiga Motif Sosial [D. McClelland], meliputi, [1] Kebutuhan untuk Berprestasi, dorongan untuk mengungguli dengan standart tertentu. [2] Kebutuhan untuk mengendalikan, dorongan untuk memengaruhi, dan memainkan tanggung jawab dengan tangan orang lain.[3] Kebutuhan untuk Berafiliasi, dorongan untuk berhubungan dengan baik, ramah dengan orang lain.

c) Teori Dua Faktor [Frederick Herzberg], melipiti, [1] Job Contex/extrinsic Factor/Satisfier Factor, merupakan suatu kondisi atau keadaan yang pendorong bagi individu untuk melakukan suatu pekerjaan. Seperti lingkungan kerja, kebijakan, gaji, dll. [2] Job Content/Intrinsic Factor/Hygiene Factor, merupakan dorongan psikis yang menirik beratkan pada muatan kerja yang mendukung perkembangan dan pertumbuhan diri.

d) Teori ERG [Clayton Alderfer], meliputi, [1] Existence, berkaitan

${ }^{3}$ Moh. As'ad, Psikologi Indusrtri: Seri Ilmu Sumber Daya Manusia, (Yogyakarta: Liberty, 1998), hlm. 49-52

FALASIFA, Vol. 9 Nomor 2 September 2018 | 23 
dengan dorongan kebutuhan untuk mengukuhkan eksistensi diri. Term ini mengkafer kebutuhan fisiologis dan kebutuhan keamanan. [2] Relatedness, berkaitan dengan dorongan akan kebutuhan membangun dan membinan hubungan. Term ini mengkafer kebutuhan sosial dan penghormatan. [3] Growth, berkaitan dengan dorongan akan kebutuhan untuk mengekspresikan diri. Term ini mencakup kebutuhan untuk mengaktualisasikan diri.

\section{Process Theory}

Teori ini menawarkan suatu pemahaman tentang bagaimana seseorang bekerja dengan pola hubungan kausalitas (Sebab-akibat). Sehingga ia berhak untuk mendapatkan sesuatu sesuai dengan kerja yang ia lakukan.

a) Expactansy Theory [Vroom], mengatakan bahwa seseorang akan terdorong untuk melakukan sesuatu apabila mereka yakin bahwa apa yang mereka lakukan mengarah dapa suatu tujuan. Unsur penting dalam teori ini adalah, [1] Expactance/harapan, kesempatan yang diberikan untuk tercapainya suatu tujuan, [2] Valence/Nilai, hal ini muncul karena adalah suatu perilaku tertentu yang mengakar tentang suatu keberhasilan yang hendak dicapai. [3] Instrumentality/pertautan, berkaitan dengan persepsi individu pada capaian tahap pertama yang kemudian berharap besar akan memperoleh capaian yang sama pada tahap berikutnya.

b) Equity Theory, [Stacy Adams], suatu dorongan untuk melakukan suatu perilaku atas dasar keadilan atau keberimbangan kerja. Sehingga jika ia merasa diperlakukan tidak adil maka ia akan berusaha mengurangi kinerja menuju kondisi yang adil atau seimbang.

c) Reinforcement Theory, Merupakan suatu dorongan perilaku yang didasarkan pada keadaan sebelumnya. Sehingga perilaku baik sebelumnya akan cenderung diulangi dan perilaku buruk sebelumnya cenderung tidak diulangi.

d) Goal Setting Theory [Edwin Locke], yang mengatakan bahwa motivasi merupakan dorongan akan kejelasan tujuan yang hendak dicapai.

Dari dua kelompok besar teori di atas, sebagian ada yang berfokus pada dorongan-dorongan yang didasarkan pada kebutuhan dan kepuasan, sementara sebagian yang lain berfokus pada perilaku kerja yang profesional. Jika dapat dikatakan, teori proses merupakan dasar bagi terciptanya suatu kerja profesional. Walaupun di sisi lain nampak transaksional. 


\section{Macam-macam Motivasi}

Jika telah sepakat bahwa motivasi merupakan dorongan psikis yang terepresentasikan dalam suatu perilaku, maka dapat dikatakan bahwa motivasi memiliki dua dimensi, yaitu dimensi psikis dan perilaku. Kajian tentang motivasi ini kemudian dapat dilihat dari banyak aspek. Dilihat dari sisi metodenya, motivasi dapat dikategorikan menjadi dua macam, yaitu: ${ }^{4}$

1. Direct Motivation, model yang dapat dilakukan secara langsung kepada setiap individu untuk memenuhi kebutuhan dan kepauasan kerjaanya. Bentuk ini dapat bewujud materi atau moril, seperti memberikan hadiah, pujian, apresiasi dan bentuk penghargaan langsung lainnya.

2. Indirect Motivation, model motivasi yang diberikan secara tidak langsung terhadap individu, melainkan dalam bentuk pemberian fisilitas yang dapat mendukung terhadap gairah kerja, kondisfitas dan segala bentuk kenyamanan fasilitas lainnya.

Sedangkan dilihadat dari sumbernya, motivasi dapat dibagi menjadi dua macam, yaitu:

1. Motivasi Intrinsik/internal, yaitu motivasi yang berasal dari dalam diri individu yang mendorong perilaku.

2. Motivasi Ekstrinsik/eksternal, yaitu motivasi yang berasal dari luar diri individu atau reward yang diberikan oleh pihak pihak lain.

Dua cara memberikan motivasi ini dapat dilakukan oleh seorang manajer atau pimpinan dalam suatu lembaga pendidikan Islam secara bersamaan. Pemberian motivasi secara langsung dapat diperankan oleh pimpinan dalam kapasitasnya sebagai seorang leader, mengingat bentuk tersebut membutuhkan cara-cara yang elegan. Hal ini berbeda dengan kapasitasnya sebagai seorang manajer, karena manajer memiliki kecenderungan yang formal nan normatif. Sedangkan motivasi tidak langsung sejatinya merupakan pendukung dari motivasi langsung. Namun demikian keberadaanya merupakan aspek penting yang mendukung suasana kerja yang bersemangat dan kondusif.

\section{Faktor Pendorong Motivasi}

Adapun hal-hal yang dapat menjadi pendorong seseorang dalam melakukan perilaku tertentu dalam sebagai berikut: ${ }^{5}$

1. Faktor Internal

${ }^{4}$ Malayu S. P. Hasibuan, Manajemen Sumber Daya Manusia, (Yogyakarta: Bumi Aksara, 2006), hlm. 149

${ }^{5}$ Munandar, Psikologi Industri dan Organisasi, (Depok: UI Press, 2001), hlm. 21

FalAsIfa, Vol. 9 Nomor 2 September 2018 | 25 
a. Responsibility, besar kecilnya tanggung jawab yang dirasakan oleh individu akan menjadi fakor pendorong motivasi.

b. Advencement, besar kecilnya seorang individu untuk dapat maju dengan pekerjaan yang diembannya.

c. Employment, besar kecilnya tantangan pekerjaan yang dirasakan oleh invidu.

d. Achievement, besar kecilnya kemungkinan individu untuk dapat berprestasi dengan pekerjaan yang ditekuninya.

e. Recognition, besar kecilnya pengakuan yang diberikan untuk suatu pekerjaan.

Teori motivasi yang cenderung kearah faktor ini adalah Two factor Theory dan teori kebutuhan Maslow. Hal ini dapat dilihat dari pemetaan sebelumnya bahwa teori isi atau content theory berkaitan dengan Instrinsic Motivation. Sehingga hal-hal yang menjadi pendorong yang bersumber dari dalam diri invidu dapat dikatakan sebagai faktor pendorong internal. Seperti usia, kebutuhan, ambisi, dll.

Sedangkan Menurut Saydam, faktor internal dapat dipengaruhi oleh hal-hal berikut ini: ${ }^{6}$

a. Kematangan Pribadi, hal ini berkaitan dengan kondisi ego seseorang, dimana sebagian individu remaja masih belum bisa melakukan aktifitas secara profesional

b. Tingkat Pendidikan, tinggi rendahnya pendidikan akan memengaruhi terhadap persepsi seseorang terhadap suatu pekerjaan.

c. Keinginan dan Harapan Pribadi, harapan dan ambisi merupakan faktor intrinsik yang dapat menggerakkan seseorang.

d. Kebutuahan, biasanya kebutuhan akan menjadi mesin penggerak bagi seseorang dalam melakukan aktifitas.

e. Kelelahan dan Kebosanan, kondisi fisik dan psikis seseorang akan berpengaruh terhadap motivasi kerja.

f. Kepuasaan Kerja, hal ini berkaitan dengan pola pelayanan yang dirasakan oleh individu dalam bekerja.

Keseluruhan faktor ini akan menjadi pemicu seseorang dalam melakukan pekerjaan yang profesional. Semakin besar dorongan yang bersumber dari dalam dirinya akan semakin nampak perilaku positif yang dimunculkannya. Hal yang demikian ini merupakan sebuah keniscayaan bagi setiap orang.

${ }^{6}$ Kadarisman, Manajemen Pengembangan Sumber daya Mamusia, (Jakarta: Raja Grafindo Persada, 2012), hlm. 295

26 | FaLASIFA, Vol. 9 Nomor 2 September 2018 
Pengembangan Sistem Peningkatan Motivasi, Komitmen Dan Moralitas SDM...

2. Faktor Eksternal

Adapun faktor ekstenal yang memengaruhi motivasi kerja adalah sebagai berikut: ${ }^{7}$

a. Kondisi Lingkungan Kerja, lingkungan bisa mencakup sarana dan prasarana, namun juga bisa muncakup kondusifitas dan iklim kerja.

b. Kompensasi yang Memadai, walaupun tidak semua orang bekerja untuk uang, namun kompensasi tetap merupakan harapan dan pendorong bagi individu.

c. Supervisi yang Baik, bagi sebagian orang, diawasi atau tidak, akan tetap menampilkan perilaku kerja yang baik, namun kehadiran pimpinan ditengah karyawan organsiasi akan menjadi suntikan motivasi bagi banyak orang.

d. Jaminan Karir, hal ini sebagai bentuk apresiasi berjenjang yang dapat menjadi pendorong bagia individu dalam bekerja.

e. Status dan Tanggung Jawab, perbedaan status dan tanggung jawab dalam organisasi merupakan sebuah keniscayaan. Sehingga besar kecilnya tanggung jawab, tinggi rendahnya status, relevan tidaknya suatu pekerjaan, akan menjadi motivasi bagi karyawan.

f. Peraturan yang Fleksibel, peraturan yang kaku cenderung membelenggu kreatifitas karyawan untuk melakukan aktifitas, sehingga kenyamanan tidak mudah tercipta. Kondisi yang demikian itu menuntut adanya fleksibelitas dalam regulasi yang dapat mendorong motivasi karyawan dalam bekerja.

Aspek eksternal di atas tidak hanya menyangkut aspek manajerial saja, melainkan harus dapat dilakukan secara personal oleh pimpinan terhadap bawahan. Lebih-lebih dalam dunia pendidikan, dimana pendidikan dituntut untuk melakukan perlakuan yang humanis terhadap seluruh elemen melalui pendekatan personal.

\section{Komitmen SDM Lembaga Pendidikan Islam}

Menurut Wibowo, Komitmen adalah Identifikasi perasaan terhadap organisasi yang dibarengi keterlibatan diri dengan penuh loyalitas. ${ }^{8}$ Definisi ini memberikan tiga unsur penting dalam komitmen organisasi,yaitu, Identifikasi diri, Loyalitas dan Keterlibatan diri. Pengertian lain dikemukakan oleh Mowday bahwa

\footnotetext{
7 Kadarisman, Manajemen Pengembangan Sumber daya Manusia, hlm. 296

${ }^{8}$ Fannidia Ifani Putri, Hubungan motivasi Kerja dengan Komitmen kerja karyawan di Balai Pendidikan dan pelatihan Sosial, Junral Administrasi Pendidikan, Vol. 2, No. 1, Juni 2014, hlm. 220
}

FALASIFA, Vol. 9 Nomor 2 September 2018 | 27 
komitmen adalah dimensi penting yang digunakan untuk menilai kecenderungan perilaku karyawan untuk bertahan sebagai anggota organisasi. ${ }^{9}$ Makna ini lebih praktis dari pada pengertian pertama, dimana seseorang dapat dikatakan komitmen manakalah ia bertahan dalam organisasi untuk kepentingan produktifitas dan profesionalisme kerja. Pertimbangan produktifitas ini menafikan suatu komitmen konyol yang bertahan dalam organisasi yang kurang bernilai manfaat.

\section{Dimensi Komitmen}

Berikut ini adalah dimensi penting dalam komitmen organisasional yang harus fahami: ${ }^{10}$

\section{Komitmen Afektif}

Berhubungan dengan kondisi emosional anggota terhadap organisasinya. Idenfikasi dengan organisasi, keterlibatannya hingga loyalitasnya sudah menjadi satu kesatuan dalam organisasinya. Ia akan sulit untuk dipisahkan dalam kondisi apapun.

2. Komitmen Berkelanjutan

Berkaitan dengan kesadaran anggota akan kerugian dirinya jika ia meninggalkan organisasinya. Anggota dengan komitmen kontinum yang tinggi akan tetap bertahan hingga organisasinya berakhir.

3. Komitmen normatif

Keterikatan anggota dengan organisasi yang dipengaruhi oleh normatifitas, baik itu dari sisi undang-undang, tradisi maupun ideologis.

Tiga dimensi komitmen ini dapat digunakan untuk memetakan anggota organisasi yang ikut dengan pertimbangan perasaan, rasionalitas atau hanya ikutikutan komitmen. Hal ini juga dapat dijadikan sebagai tipologi komitmen anggotan terhadap organisasinya. Pertimbangan kesamaan visi, pemahaman, nampaknya lebih positif dibanding hanya berkomitmen lantaran pertimbangan suka atau tidak suka.

\section{Faktor pendorong Komitmen}

Berikut ini adalah faktor yang dapat mendorong terciptanya komitmen organisasi: ${ }^{11}$

\footnotetext{
${ }^{9}$ Sopiah, Perilaku Organisasi, (Yogyakarta: Andi Offset, 2008), hlm. 155

${ }^{10}$ Mayer and Allen J. Natalie, A Three Component Conceptualization of Organization Commitment, Jurnal, Vol. 1, No. 1, Tahun 1991, hlm. 61-89

${ }^{11}$ Sopiah, Perilaku Organisasi, hlm. 164
}

28 | FaLASIFA, Vol. 9 Nomor 2 September 2018 


\section{Faktor Personal}

Adanya individu yang memang secara personal selalu bekerja secara profesional tidak dapat dipungkiri. Motivasi intrinsik lah sebenarnya yang menggerakannya menjadi seseorang yang berkomitmen diri bagi organisasi untuk dapat bekerja dengan baik. Faktor idealisme dan loyalitas memang tidak bisa diukur dengan standart normal. Karena ia akan menjadi pengikat antara dirinya dan organisasi. Seperti, Espektiasi kerja dan kesesuaian pilihan kerja.

2. Faktor Organisasi

Perlakuan yang istimewa, pelayanan yang prima, fasilitas yang memanjakan memang menjadi pendorong seseorang untuk dapat loyal terhadap organisasi. Pelatihan, orientasi yang dilakukan dalam organisasi, baik pendidikan maupun industri, sebenarnya memiliki tujuan ganda, yakti menumbuhkan komitmen dan kompetensi. Seperti, Pengalaman kerja, Konsistensi tujuan dan pelatihan.

3. Non Organisasi

Kenyamanan komunikasi antara anggota organisasi merupakan suasana yang dapat mendukung terhadap terciptanya komitmen anggota. Saling tukar nilai, ideologi memicu seseorang untuk membangun kesefahaman yang produktif bagi organisasinya. Mengingat, tidak semua organiasi dengan sengaja mencipatakan suasana kerja yang harmoni melainkan bisa saja terbentuk dengan sendirinya. Seperti terbukanya peluang kerja alternatif.

Uraian ini dapat dijadikan sebagai tolok ukur dalam mengetahui tingkat komitmen seseorang dalam organisais. Di antaranya adalah, adanya keyakinan dan penerimaan yang kuat terhadap tujuan organisasi dan nilainilai di dalamnya. Kemudian dapat juga dilihat dari adanya kesediaan untuk berusaha semaksimal mungkin demi kepentingan organisasi. Di samping itu juga dapat diketahui dari adanya keinginan untuk mempertahankan kenggotaan organisasi. Hal yang demikian ini merupakan indikator teknis yang mudah dijumpai dalam organisasi pendidikan.

\section{Moralitas SDM Lembaga Pendidikan Islam}

Pemahaman umum tentang moral biasanya berkaitan dengan budi pekerti manusia yang berkaitan dengan adab. Secara lebih luas lagi moral dapat dipahami sebagai ajaran yang berkaitan dengan baik dan buruk, patut atau tidak patut. Sehingga berdasarkan proposisi ini kajian moral dapat dibedakan menjadi dua 
macam: ${ }^{12}$

1. Moral murni, yang bermakna nilai-nilai ilahi yang terjawantahkan dalam diri individu. Moral murni juga disebut sebagai hati nurani.

2. Moral terapan adalah tata nilai yang didapat dari ajaran pelbagai ajaran folisofis, agama, adat yang menguasai manusia.

Definisi ini mengisyaratkan bahwa moral berkaitan dengan tata nilai, faham individu tentang perilaku-perilaku individu dan kelompok. Jika dikaitkan dengan filosofi dan adat, maka dapat dipastikan bahwa moral berkaitan dengan hal-hal yang prinsip dalam suatu komunitas. Lebih jauh lagi, moral berkaitan dengan nilai-nilai universal dalam kondisi manapun. Kejujuran, semangat dan motivasi merupakan bagian dari moralitas yang berlaku umum dalam kondisi apapun.

Dalam kontes sumber daya manusai, moral SDM bermakna keadaan atau kondisi mental yang membuat orang tetap berani, bersemangat dan bergairah. ${ }^{13}$ Pengertian ini selaras dengan pendapat Jewell dan Siegall tentang moralitas kerja, yaitu keadaan pikiran dan emosi yang memengaruhi seseorang bekerja dan mengarahkan kembali pada tujuan individu atau tujuan organisasi. ${ }^{14}$

Dua pengertian ini memiliki dua dimensi utama, yaitu mental yang berani, bersemangat dan bergairan, kemudian berpengaruh terhadap pola kerja demi kepentingan organisasi. Terwujudnya Semangat dan gairah kerja yang tinggi sebagai indikator dari baiknya moralitas kerja seseorang. Orang yang memiliki moralitas kerja yang baik, tidak selalu bekerja untung kepentingan materi. Termenologi ini dalam istilah lain dikenal dengan etos kerja.

\section{Faktor yang Mendorong Munculnya Moralitas}

Menurut Sumaryoni yang dikutip oleh Rivai, terdapat tiga faktor yang mendorong muculnya moralitas bagi individu: ${ }^{15}$

1. Motivasi, dorongan psikis seseorang yang muncul secara intrinsik akan menjadikan seseorang memiliki semangat, gairah dan intensitas kerja yang baik.

2. Tujuan, adanya ambisi untuk menggapai target di ujung proses menjadikan seseorang memiliki etos kerja yang baik.

3. Lingkungan, tidak dapat dipungkiri bahwa lingkungan ikut andil dalam

${ }^{12}$ Veithzal Rivai, Pemimpin dan Kepemimpinan dalam Organisasi, (Jakarta: Raja Grafindo Persada, 2014), hlm. 102

${ }^{13}$ Salim, Struktur dan Proses Sosial, (Jakarta: Rajawali Press, 2001), hlm. 67

${ }^{14}$ Jewell dan Siegall, Psikologi Industri dalam Organisasi Modern, Alih Bahasa, Pudjaatmaka, (Jakarta: Arcan, 1998 ), hlm. 98

${ }^{15}$ Veithzal Rivai, Pemimpin dan Kepemimpinan dalam Organisasi, hlm. 102

30 | FALASIFA, Vol. 9 Nomor 2 September 2018 
Pengembangan Sistem Peningkatan Motivasi, Komitmen Dan Moralitas SDM...

mengkonstruk suatu tatanan sosial, pola nilai individu yang tercermin dalam intraksi sosialnya.

Komitmen, motivasi dan moralitas SDM merupakan dorongan psikis yang dipengaruhi oleh banyak faktor. Di samping dorongan psikis, kondisi lingkungan dan visi organisasi juga dapat memberikan konstribusi terhadap pola kerja seseorang. Organisasi, baik pendidikan maupun non pendidikan yang tidak memiliki arah yang jelas, pola kerja anggotanya cenderung tidak bersemangat dan tanpa cita-cita.

\section{Aspek-asek pengukuran Moral}

Menurut Maier, terdapat beberapa aspek dalam mengukur moralitas kerja individu dalam organisasi: ${ }^{16}$

1. Gairah dan antusiasme

2. Kualitas untuk bertahan

3. Kekuatan untuk melawan frustasi

4. Semangat berkelompok

Secara lebih teknis, menurut Nitisemito aspek moralitas kerja dapat diukur dari sikap berikut ini: ${ }^{17}$

1. Sikap terhadap pekerjaan, yang meliputi perasaan senang terhadap pekerjaan yang sesuai peniliain terhadap pekerjaannya.

2. Sikap terhadap pimpinan yang meliputi, perhatian atasan, hubungan dengan atasan, keterbukaan atasan.

3. Sikap terhadap perusahaan yang meliputi lingkungan kerja, kebijakan organisasi, kerjasama, hubungan dengan teman kerja.

Berdasarkan aspek-aspek ukur di atas, moralitas menyangkut peneriaan terhadap kebijakan, kerjasama dengan kelompok kerja dan loyalitas terhadap pimpinan. Sehingga hubungan organisasional dan hubungan personal dapat dikembangan oleh masing-masing individu demi kepentingan tercapainya tujuan organisasi.

16 Maier J.B, Manajemen Era Baru: Beberapa Pandangan Mengenai Budaya Perusahaan Modern, (Jakarta: Erlangga, 1996), hlm. 45

${ }^{17}$ Nitisemito S. A, Manajemen Personalia, (Jakarta: Ghalia, 2000), hlm. 74

FALASIFA, Vol. 9 Nomor 2 September 2018 | 31 
Model Pengembangan Sistem Peningkatan Motivasi, Komitmen dan Moralitas SDM di Lembaga Pendidikan Islam

Tabel Model Pengembangan Peningkatan Motivasi, Komitmen dan Moralitas SDM Lembaga Pendidikan Islam

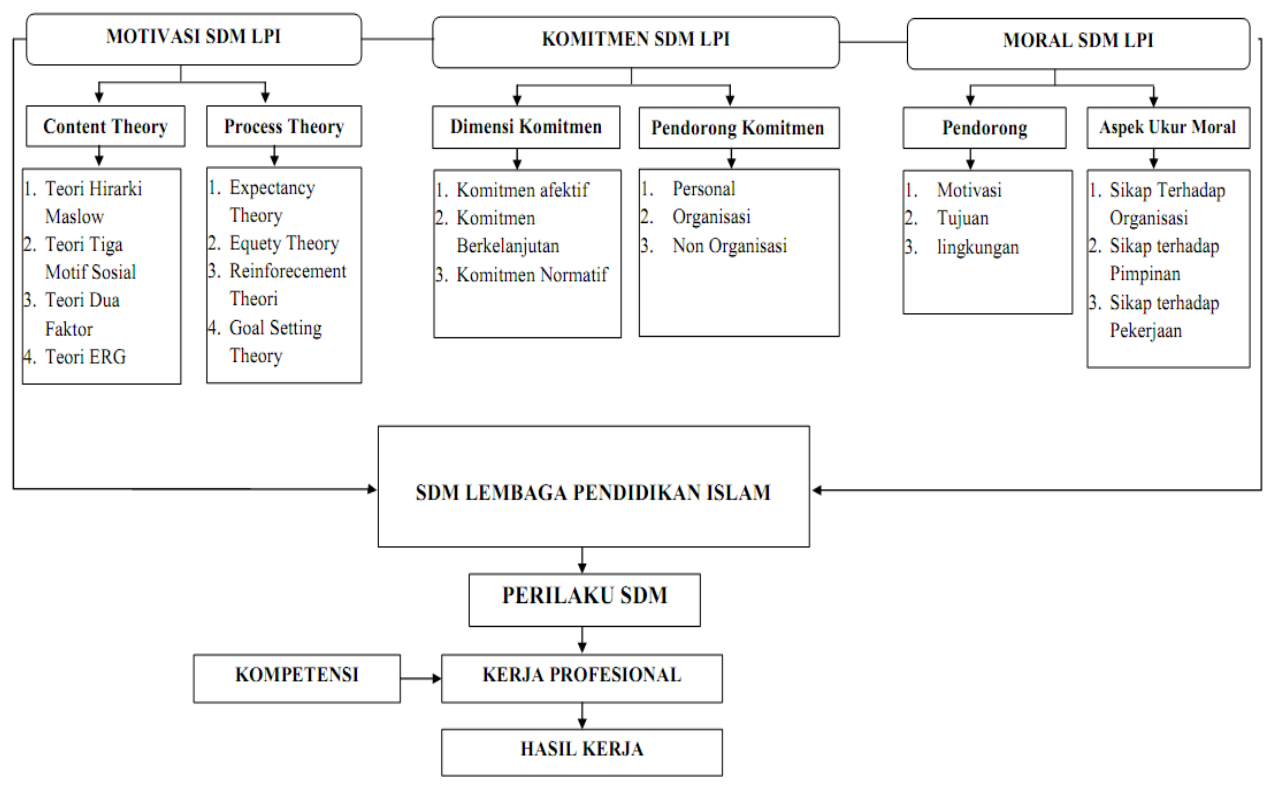

\section{PENUTUP}

Berdasarkan uraian di atas, dapat disimpulkan sebagai berikut:

1. Motivasi SDM berhubungan dengan dorongan-dorongan psikis yang dipengaruhi oleh dua faktor, yaitu internal dan eksternal, atau instrinsik dan ekstrinsik. Faktor internal dapat dipengaruhi oleh kebutuhan dasar manusia sebagaiamana teori Maslow.

2. Komitmen SDM berhubungan dengan identifikasi perasaan, keikutsertaan dan loyalitas terhadap organisasi. Sehingga jika hendak mengetahui komitmen seseorang maka dapat melihat loyalitasnya terhadap organisasi. Hal ini dapat juga dipengaruhi oleh motivasi, kesamaan tujuan, materi dan non materi lainnya.

3. Moralitas SDM sejatinya merupakan istilah lain dari etos kerja. Mereka yang memiliki etos kerja yang baik cenderung menampilkan perilaku kerja yang profesional. Dengan bekal kepatutan, seseorang dapat berfikir, berperilaku yang sesuai dengan posisi dan tanggung jawab yang diembannya.

4. Secara teoritis, pengembangan Sistem peningkatan motivasi, Komitmen, moralitas SDM dapat memberikan pengaruh terhadap terciptanya perilaku

32 | FalASIFA, Vol. 9 Nomor 2 September 2018 
Pengembangan Sistem Peningkatan Motivasi, Komitmen Dan Moralitas SDM...

kerja yang profesional. Namun demikian, untuk hasil yang maksimal harus juga didukung oleh kompetensi yang mendukung terhadap produktifitas kerja.

\section{DAFTAR PUSTAKA}

Fannidia Ifani Putri, Hubungan motivasi Kerja dengan Komitmen kerja karyawan di Balai Pendidikan dan pelatiban Sosial, Junral Administrasi Pendidikan, Vol. 2, No. 1, Juni 2014,

Jewell dan Siegall, Psikologi Industri dalam Organisasi Modern, Alih Bahasa, Pudjaatmaka, (Jakarta: Arcan, 1998 ),

Kadarisman, Manajemen Pengembangan Sumber daya Manusia, (Jakarta: Raja Grafindo Persada, 2012),

Maier J.B, Manajemen Era Baru: Beberapa Pandangan Mengenai Budaya Perusahaan Modern, (Jakarta: Erlangga, 1996),

Malayu S. P. Hasibuan, Manajemen Sumber Daya Mamusia, (Yogyakarta: Bumi Aksara, 2006),

Mayer and Allen J. Natalie, A Three Component Conceptualization of Organization Commitment, Jurnal, Vol. 1, No. 1, Tahun 1991,

Moh. As'ad, Psikologi Indusrtri: Seri Ilmu Sumber Daya Manusia, (Yogyakarta: Liberty, 1998),

Munandar, Psikologi Industri dan Organisasi, (Depok: UI Press, 2001),

Nitisemito S. A, Manajemen Personalia, (Jakarta: Ghalia, 2000),

Robbins P. Stephen, Perilaku Organisasi, Alih Bahasa: Tim Indeks, (Jakarta: PT. Indeks Kelompok Gramedia, 2003),

Salim, Struktur dan Proses Sosial, (Jakarta: Rajawali Press, 2001),

Sopiah, Perilaku Organisasi, (Yogyakarta: Andi Offset, 2008),

Veithzal Rivai, Manajemen Sumber Daya Manusia untuk Perusahaan, (Jakarta: PT. Raja Grafindo Persada, 2005),

------- Pemimpin dan Kepemimpinan dalam Organisasi, , (Jakarta: PT. Raja Grafindo Persada, 2005),

Pemimpin dan Kepemimpinan dalam Organisasi, (Jakarta: Raja Grafindo Persada, 2014), 


\section{Fauzan Adhim}

34 | FaLASIFA, Vol. 9 Nomor 2 September 2018 